\title{
The success pregnancy rate with estrous synchronization hormones in Madura cow
}

\author{
Jauhari Efendy ${ }^{1)}$ and Muchamad Luthfi ${ }^{1 *}{ }^{*}$ \\ 1) Loka Penelitian Sapi Potong \\ Jl. Pahlawan No. 2 Grati, Pasuruan, Provinsi Jawa Timur 67184
}

Submitted: 19 January 2019, Accepted: 04 October 2019

\begin{abstract}
This study aimed to determine the efficiency and effectiveness of the use of PGF2 $\alpha$ and ovsynch (PGF2 $\alpha$ and GnRH) estrous synchronization hormones on their ability to have an impact in the form of estrous and pregnancy symptoms in Madura cow. The material used were 182 Madura cows, was consisted by three treatments, namely A treatment with 62 cows; first day (H-0) was injected with PGF2 $\alpha$ dose of $2 \mathrm{ml}$; 11 th day (H-11) injected with the same hormone and dosage; then 3-4 days after the second AI (Artificial Insemination) injection directly; treatment B of 60 cows; first day (H-0) injected PGF2 $\alpha$ dose $3 \mathrm{ml}$; 11 th day (H-11) is injected again with the same hormone and dosage; then 3-4 days after injection of the second hormone directly AI; $\mathrm{C}$ treatments were 60 cows; given ovsynch treatment; that is, on the first day (H-0) injected with a $2.5 \mathrm{ml}$ dose of the GnRH hormone; 8th day $(\mathrm{H}-$ 8) injected with PGF2 $\alpha$ dose $2 \mathrm{ml}$; the 10th day was injected again with the second GnRH hormone (2.5 $\mathrm{ml}$ dose), then the 11th day was directly AI. Sampling was done by purposive sampling method, which was choosing a cow that has a body condition score (BCS) between 5-7, normal reproductive organs and not in a state of pregnancy. The study design used a completely randomized design; Data were analyzed using the Kruskal Wallis test. The results showed that the administration of synchronous hormones to the percentage of estrous and pregnancy rate in all treatments showed no significantly different results $(\mathrm{P}>0.05)$. The average percentage of estrous Madura cows in all treatments was $94.50 \%$, while the average pregnancy rate was $68.66 \%$, the highest yield in treatment $\mathrm{C}$ was $73.33 \%$; followed by treatments A and B respectively $70.97 \%$ and $61.67 \%$.
\end{abstract}

Keywords: Madura cow; estrous synchronization; pregnancy rate.

*Corresponding Author: luthfi.m888@gmail.com 


\section{INTRODUCTION}

Food availability is a big problem to many countries because food is a basic need for human survival. This phenomenon directly requires the availability of beef cattle in sufficient quantities. On the other hand, the fulfillment of national beef is currently experiencing a shortage of supply as a result of an unbalanced increase in cattle population compared to national needs so that imports of feeder cattle and frozen meat are still large enough; namely reaching $35-40 \%$.

Madura cattle are a type of dualfunction cattle (for work and meat) that have a significant contribution to the country's meat supply. As an asset of genetic resources (germplasm) native to Indonesian cattle, the existence of Madura cattle must be maintained both in terms of population and genetic purity (Nijman et al., 2003). The development of the Madura cattle population can work well if reproductive traits such as the birth interval and postpartum anesthesia period are at favorable levels.

A breakthrough for increasing local beef cattle population is by producing calves in large quantities in the same relative time through estrous synchronization technology using prostaglandin (PGF2 $\alpha$ ) and ovsynch (a combination of the PGF $2 \alpha$ and GnRH hormone). The use of the synchronization hormone is needed considering the appearance of estrous in each individual animal is different, as well as between breeds in cattle. Jiménez et al., (2011) reported that cows from Bos indicus tend to show low lust intensity and short duration of estrous compared to other cattle breeds.

Estrous synchronization is a way to uniform a marriage program within a certain period and usually uses a combination of two or three hormones; namely progestins, prostaglandins and GnRH (Hall et al., 2008) The benefits obtained from this program include optimization and efficiency of
Artificial Insemination (AI) implementation, overcoming problems of recognition/detection of estrous, overcoming certain reproductive problems such as anesthesia post partus and facilitation of early marriage programs after childbirth

\section{MATERIALS AND METHODS Research Materials and Locations}

The material used were 182 Madura cows owned by community breeders, most of which were "Sonok" cows, namely ornamental or exotic cows that were specially kept for their beauty and harmony. Based on the physiological status, the study material was divided into two: 77 heads and 105 heads were divided into three treatments based on the dose and type of hormone injected. The hormone product used was Prostaglandin (PGF2 $\alpha$ ) with the brand Lutelyse and Gonadotrophin Releasing Hormone $(\mathrm{GnRH})$ brand Fertagyle.

This research lasted for five months (June - October); located in three subdistricts of the Sonok cattle development center namely Waru, Pasean, and Batumarmar Districts, Pamekasan Regency, Madura, East Java. Sampling was done by purposive sampling method, the cows chosen had a body condition score (BCS) between $5-7$, the condition of the normal reproductive organs of pregnancy; it was very important to note because a pregnant cow when injected with the hormone estrous synchronization would been experience an abortion.

\section{Research Methods}

Before cows were injected with the hormone estrous synchronization, first an initial examination was done through rectal palpation which aimed to determine the condition of the reproductive organs and pregnancy. Furthermore, the cows that had been selected were injected with the hormone prostaglandin (PGF2 $\alpha)$ in different doses and ovsynch. According to 
Cartmill et al., (2001) prostaglandin injection plays a role in rejuvenating the corpus luteum in the luteal phase; whereas ovsynch is a method of estrous synchronization which in its application combines the use of prostaglandins (PGF2 $\alpha$ ) and GnRH so that estrous and ovulation occur simultaneously (Cartmill et al., 2001). The method of injecting estrous synchronization hormone was done intramuscular (IM) based on three treatments as follows:

- Treatment A: 62 Madura cows (51 normal); on the first day (H-0) injected with the hormone PGF $2 \alpha$ dose of $2 \mathrm{ml}$; then the 11th day (H-11) was injected again with the same hormone and dose. Then 3-4 days after injection of the second hormone directly in the AI (both showing symptoms of estrus or not).

- Treatment B: 60 Madura cows (54 normal); on the first day (H-0) injected with the PGF2 $\alpha$ dose $3 \mathrm{ml}$; then the 11th day (H-11) was injected again with the same hormone and dose. Then 3-4 days after injection of the second hormone directly in the AI (both showed symptoms of estrus or not).

- Treatment C: 60 Madura cows (46 of which are normal); given ovsynch treatment; that was, on the first day $(\mathrm{H}-$ 0 ) injected with a $2.5 \mathrm{ml}$ dose of the GnRH hormone; day 8 (H-8) was injected with the PGF2 $\alpha$ hormone dose of $2 \mathrm{ml}$; the 10th day was injected again with the second GnRH hormone (dose $2.5 \mathrm{ml})$. Then the 11th day was immediately AI (both showing symptoms of estrus or not).

The parameters used were estrous intensity, estrous percentage and pregnancy rate. Estrous intensity was observed based on estrous signs which included four indicators namely red vulva, swollen and mucous discharge, and riding on other cows; the percentage of estrous was calculated based on the number of estrous cows divided by the total number of treatment cows multiplied by one hundred percent; while pregnancy rate was calculated based on the number of pregnant cows divided by the total number of treatment cows multiplied by one hundred percent.

Insemination was carried out 6-8 hours after the estrous cow by inserting an insemination gun containing semen into the female reproductive organ of the cow. Thawing uses well water with a duration of between 15-20 seconds. Rectal pregnancy checked by rectal palpation performed 2 (two) to 3 (three) months after the cows were treated in AI.

\section{Research Design and Data Analysis}

This research was conducted using a Completely Randomized Design (CRD) in one direction with three treatments. The data obtained were processed and analyzed using the Kruskal Wallis test using the SPSS Windows Version 23 program (Sugiyono et al., 2015).

\section{RESULTS AND DISCUSSION Initial inspection}

An initial examination was performed with rectal palpation, the aimed to determine the condition of the reproductive organs and pregnancy status. Data from the initial inspection of Madura cows in each treatment are presented in Table 1.

The reproduction performance of Madura cows was quite good although faced with conditions of limited quality and quantity of feed. It was indicated by the condition of the reproductive organs which are mostly in normal condition, both cows in treatment A, B, and C; namely $82.26 \%$ each; $87.10 \%$ and $76.67 \%$. However, the proportion of CLP (corpus luteum persistent) was also quite large; both in treatments $\mathrm{A}, \mathrm{B}$ and $\mathrm{C}$, respectively $16.16 \% ; 10.00 \%$ and $23.33 \%$. Putro (2009) states that CLP is caused by endometrial disorders; so the treatment must be directed at the treatment of the endometrium and the 
destruction of the CL (corpus luteum). In contrast to ovarian hypofunction have symptoms of normal ovarian size, but no detected follicles - growth follicles, characterized by a smooth ovarian surface without a structure that contains fluid (follicles). Possible causes were lack of nutritional supply for the physiological process of follicle formation, the proliferation of granulosa cells and oocyte maturation, as well as very low concentrations of FSH in the blood that are unable to trigger follicular development. (Rosadi et al., 2018).

Table 1. Results of initial inspection of Madura cows

\begin{tabular}{|c|c|c|c|c|c|c|c|c|}
\hline \multirow{3}{*}{ No. } & \multirow{3}{*}{ Treatment } & \multicolumn{6}{|c|}{ Conditions of Reproduction } & \multirow{3}{*}{$\begin{array}{l}\text { Amount } \\
\text { (head) }\end{array}$} \\
\hline & & \multicolumn{2}{|c|}{$\begin{array}{c}\text { Normal } \\
\text { (head) }\end{array}$} & \multicolumn{2}{|c|}{$\begin{array}{c}\text { Ovarian } \\
\text { Hypofunction } \\
\text { (head) }\end{array}$} & \multicolumn{2}{|c|}{$\begin{array}{l}\text { CLP } \\
\text { (head) }\end{array}$} & \\
\hline & & Cow & Heifer & Cow & Heifer & Cow & Heifer & \\
\hline 1. & A & 18 & 33 & 1 & - & 7 & 3 & 62 \\
\hline 2. & B & 21 & 33 & - & - & 5 & 1 & 60 \\
\hline 3. & $\mathrm{C}$ & 20 & 26 & - & - & 5 & 9 & 60 \\
\hline \multicolumn{2}{|c|}{ Amount (head) } & 59 & 92 & 1 & - & 17 & 13 & 182 \\
\hline \multicolumn{2}{|c|}{ Percentage $(\%)$} & 32.42 & 50.55 & 0.55 & - & 9.34 & 7.14 & 100 \\
\hline
\end{tabular}

\section{Estrus incidence and percentage}

The occurrence of Madura cows estrous in each treatment was determined based on three categories: visible estrous (apparent), pseudo estrous (silent heat) and not estrous. Data on the incidence and percentage of Madura estrous cow on the administration of prostaglandin ( 2 and $3 \mathrm{ml}$ ) estrous synchronization hormones and ovsynch (prostaglandin and $\mathrm{GnRH}$ ) are presented in Table 2. In treatments A and B, estrous observations were carried out twice a day (morning and evening) in a row for two days; whereas treatment $\mathrm{C}$ was done once, a day after being injected with the second GnRH hormone or when the cow was AI. Estrus observation was carried out by looking at some of the symptoms of estrus such as the state of the vulva (swollen, wet and red), mucus that comes out hanging through the vulva and other symptoms including restlessness or discomfort and decreased appetite.

The signs of Madura cows estrous in treatments A and B are generally seen after 2 days of the second prostaglandin hormone administration; namely 19 cows $(70.37 \%)$ and 14 cows $(53.85 \%)$ and the rest at 3 days after the administration of the second prostaglandin hormone.

Table 2. Occurrence and percentage of estrous of Madura cows

\begin{tabular}{cccccc}
\hline \multirow{2}{*}{ No. } & \multirow{2}{*}{ Treatment } & \multicolumn{3}{c}{ Estrous incidence } & \multirow{2}{*}{$\begin{array}{c}\text { Percentage } \\
\text { estrous (\%) }\end{array}$} \\
\cline { 3 - 5 } & & Visible (head) & Pseudo (head) & Not estrous (head) & 93.55 \\
1. & A & 27 & 31 & 4 & 95.00 \\
3. & B & 26 & 31 & 3 & 95.00 \\
\hline
\end{tabular}

$P>0.05$ : not significantly different.

In treatment $\mathrm{C}$, all animals that show estrous appear (clearly) was showing estrous symptoms one day after the second GnRH administration. This was resemble with the results of research conducted by Adriani et al., (2009) on Brahman crossbred cows that as many as 11 cows $(57.90 \%)$ showed signs of estrus 2 days after 
administration of PGF2 $\alpha$ and the remaining 8 cows (42.11) \%) shows signs of estrous 3 days after administration of PGF2 $\alpha$. Meanwhile according to Perry et al., (2007), cow will estrous approximately 72 hours after administration of PGF2 $\alpha$. All cows that showed estrous appear (clearly) in each treatment showed mucus coming out of the vulva, even the mucus was still seen hanging from the vulva when the cows were IB. In addition, some estrous mucus also appeared attached to the base of the tail and to the right and / or left thighs.

In the observation of behavior, it turned out that most of the cattle in all treatments that experience estrous (both visible and pseudo) show changes in behavior such as decreased appetite and anxiety. The symptoms of estrous are in accordance with the results of research conducted by Kune and Solihati (2007) that all estron synchronized cows exhibit typical symptoms such as swollen and red vulva, mucus, anxiety, and decreased appetite. The effect of synchronizing hormone administration on the percentage of estrous in all treatments was not significantly different (Table 2).

The overall percentage of estrous in Madura cattle treated with estrous synchronization hormone was quite high; which is $94.50 \%$. According to Kune and Najamudin (2002); Prihatno and Gustari (2003) and Ahola et al., (2009), that the effectiveness of estrous synchronization with PGF2 $\alpha$ was very high, reaching $100 \%$ each in beef cattle (Ongole cross breed cows) and dairy cows that were intramuscularly induced. Hyland et al., (2009) and Skarzynski et al., (2009) also reported the same thing in Holstein and beef cattle, respectively. Thus the administration of estrous synchronization hormone in Madura cows proved to be quite effective in causing visible and pseudo estrous. The onset of estrous due to administration of PGF2 $\alpha$ caused by CL lysis by the mechanism of action of PGF $2 \alpha$. As a result, progesterone levels in the blood produced by CL decrease (Hafizuddin et al., 2012); thus the ratio between estrogen and progesterone concentrations increased so that the animal will exhibit its estrous behavior patterns. Meanwhile, the administration of the GnRH hormone aims to improve the estrous cycle, ovulation, and fertility of female animals (Herbert and Trigg, 2005).

\section{Conception Rate}

Based on the analysis of variance analysis, the effect of synchronizing hormone administration on Madura cows showed results that were not significantly different between treatments (Table 3). The average pregnancy rate of Madura cows in all treatments is $68.66 \%$ where the highest in treatment $\mathrm{C}$ is $73.33 \%$; then followed by treatments $\mathrm{A}$ and $\mathrm{B}$ respectively $70.97 \%$ and $61.67 \%$ (Table 3).

The average pregnancy rate in this study was almost the same as the results of a study conducted by Efendi et al., (2015) in local cattle that was equal to $60 \%$ in the PGF2 $\alpha$ treatment group. Meanwhile, when compared with the ovsynch treatment group in the same study, the achievement of pregnancy rate was lower; but still in the high enough category. Madura cows synchronized with the ovsynch hormone (treatment C) and PGF2 $\alpha$ dose $2 \mathrm{ml}$ (treatment A) produced a higher pregnancy rate (i.e. $73.33 \%$ and $70.97 \%$ ) compared to the highest treatment $\mathrm{B}(73.33 \%)$; then followed by cattle in treatments A and B, namely pregnancy rates of $70.97 \%$ and $61.67 \%$, respectively. The high pregnancy rate in this study was in line with the opinion of Prihatno and Gustari (2003) that the administration of the hormone prostaglandin is intended for the induction of estrous where, if the hormone is combined with GnRH, it will improve synchronization and ovulation control; so as to increase pregnancy rate.

It was further said that $\mathrm{GnRH}$ which has the power to drive growth and follicle 
development can cause ovulation and be able to maintain a harmonious uterine environment for embryonic life. Therefore its use for therapy in various cases of reproduction (such as repeated mating) in cows is reliable.

Table 3. Pregnancy figures for Madura cows in each treatment

\begin{tabular}{cccc}
\hline \multirow{2}{*}{ Treatment } & \multicolumn{2}{c}{ Result Rectal Pregnancy check } & \multirow{2}{*}{ Amount (head) } \\
\cline { 2 - 3 } & Pregnancy (head) & Not Pregnancy (head) & \\
\hline A & 44 & 18 & 62 \\
B & 37 & 23 & 60 \\
C & 44 & 16 & 60 \\
\hline Amount (head) & 125 & 57 & 182 \\
\hline
\end{tabular}

$P>0.05$ : not significantly different.

Likewise, Ramli et al., (2016) state that the method of using the hormone PGF2 $\alpha$ in inducing and synchronizing estrous in female cattle requires two injections; that is, at intervals of 11 or 14 days, whereas a whole this approach provides quite high synchronization results.

\section{CONCLUSION}

The average percentage of estrous Madura cows in all treatments was $94.50 \%$, while the average pregnancy rate was $68.66 \%$ where the highest yield in treatment $\mathrm{C}$ was $73.33 \%$; followed by treatments A and $\mathrm{B} 70.97 \%$ and $61.67 \%$ respectively.

\section{REFFERENCES}

Adriani, Rosadi, B., and Depison. (2009). Penggunaan follicle stimulating hormone dan pregnant mare serum gonadotrophin untuk superovulasi pada sapi persilangan brahman. Media Peternakan, 32(3), 162-169.

Ahola, J. K., Seidel, G. E., and Whittier, J. C. (2009). Use of gonadotropinreleasing hormone at fixed-time artificial insemination at eighty or ninety-seven hours post prostaglandin F2 $\alpha$ in beef cows administered the long-term melengestrol acetate select synch. Professional Animal Scientist, 25(3), 256-261. https://doi.org/10.15 232/S1080-7446(15)30715-4

Cartmill, J. A., El-Zarkouny, S. Z., Hensley, B. A., Lamb, G. C., and Stevenson, J.
S. (2001). Stage of cycle, incidence, and timing of ovulation, and pregnancy rates in dairy cattle after three timed breeding protocols. Journal of Dairy Science, 84(5), 1051-1059. https://doi.org/10.3168/j ds.S0022-0302(01)745 65-1

Efendi, M., Siregar, T. N., Hamdan, H., Dasrul, D., Thasmi, C. N., Razali, R., Panjaitan, B. (2015). Angka kebuntingan sapi lokal setelah diinduksi dengan protokol ovsynch (conception rates of local cows after induction with ovsynch protocols). Jurnal Medika Veterinaria, 9(2). https:// doi.org/10.21157/j.med.vet..v9i2.3804

Hafizuddin, Siregar, T., Akmal, M., Melia, J., Husnurrizal, and Armansyah, T. (2012). Perbandingan intensitas berahi sapi aceh yang disinkronisasi dengan prostaglandin F2 alfa dan berahi alami. Jurnal Kedokteran Hewan - Indonesian Journal of Veterinary Sciences, 6(2). https://doi. org/10.21157/j.ked.hewan.v6i2.296

Hall, J., Lilies, A., and Whittier, W. (2008). Estrus Synchronization for Heifers. Department of Animal and Poultry Sciences and Department of Large Animal Medicine, Virginia Tech Publication.

Herbert, C. A., and Trigg, T. E. (2005). Applications of GnRH in the control and management of fertility in female animals. Animal Reproduction 
Science, 88(1-2 SPEC. ISS.), 141153. https://doi.org/10.1016/j.anirepr osci.2005.05.007

Hyland, A., Seidel, G. E., Enns, R. M., Peel, R. K., and Whittier, J. C. (2009). Intervals of five or seven days between controlled internal drugrelease insertion, gonadotropinreleasing hormone, and prostaglandin F2 $\alpha$ injections: effects on pregnancy rate and follicular size. Professional Animal Scientist, 25(2), 150-154. https://doi.org/10.15232/S1080-7446 (15)30697-5

Jiménez, A., Bautista, F., Galina, C. S., Romero, J. J., and Rubio, I. (2011). Behavioral characteristics of bos indicus cattle after a superovulatory treatment compared to cows synchronized for estrus. AsianAustralasian Journal of Animal Sciences, 24(10), 1365-1371. https:// doi.org/10.5713/ajas.2011.11032

Kune, P., and Najamudin. (2002). Respons estrus sapi potong akibat pemberian progesteron, prostaglandin $\mathrm{F} 2$ alfa dan estradiol benzoat dalam kegiatan sinkronisasi estrus pada sapi potong. Jurnal Agroland, 9(4), 380-384.

Kune, P., and Solihati, N. (2007). Tampilan berahi dan tingkat kesuburan sapi bali timor yang diinseminasi. Jurnal Ilmu Ternak Universitas Padjadjaran, 7(1), 1-5. https://doi.org/10.24198/JI T.V7I1.2223

Nijman, I. J., Otsen, M., Verkaar, E. L. C., De Ruijter, C., Hanekamp, E., Ochieng, J. W., Lenstra, J. A. (2003). Hybridization of banteng (Bos javanicus) and zebu (Bos indicus) revealed by mitochondrial DNA, satellite DNA, AFLP and microsatellites. Heredity, 90(1), 10-16. https://doi.org/10.1038/ sj.hdy.680 0174

Perry, G. A., Smith, M. F., Roberts, A. J., MacNeil, M. D., and Geary, T. W. (2007). Relationship between size of the ovulatory follicle and pregnancy success in beef heifers. Journal of
Animal Science, 85(3), 684-689. https://doi.org/10.2527/jas.2006-519

Prihatno, S., and Gustari, S. (2003). Pengaruh pemberian prostaglandin F2a dan gonadotrophin releasing hormon terhadap angka kebuntingan pada sapi perah yang mengalami kasus kawin berulang. Bulletin Fakultas Kedokteran Hewan Universitas Gajah Mada, 21(2). https://doi.org/ 10.22146/jsv.495

Putro, P. (2009). Dampak Crossbreeding terhadap Reproduksi Induk Turunannya (Hasil Studi Klinis). In Lokakarya Crossbreeding Sapi Potong di Indonesia: Aplikasi dan Implikasinya terhadap Perkembangan Ternak Sapi di Indonesia. Yogyakarta: Lustrum VIII Fakultas Peternakan Universitas Gadjah Mada.

Ramli, M., Siregar, T. N., Thasmi, C. N., Dasrul, D., Wahyuni, S., and Sayuti, A. (2016). Relation between Estrous Intensity and Estradiol Concentration on Local Cattle during Insemination. Jurnal Medika Veterinaria, 10(1), 27. https://doi.org/10.21157/j.med.vet..v10 i1.4032

Skarzynski, D. J., Siemieniuch, M. J., Pilawski, W., Woclawek Potocka, I., Bah, M. M., Majewska, M., and Jaroszewski， J. J. (2009). In vitro assessment of progesterone and prostaglandin E2 production by the corpus luteum in cattle following pharmacological synchronization of estrus. Journal of Reproduction and Development, 55(2), 170-176. https:// doi.org/10.1262/jrd.20121

Sugiyono, and Susanto, A. (2015). Cara Mudah Belajar SPSS dan LISREL. In Teori dan Aplikasi untuk Analisis Data Penelitian. Bandung: CV. Alfabeta. 